\section{ABOUT SOME MONETARY FINDS IN FUNERARY CONTEXT FROM MOESIA INFERIOR}

\begin{abstract}
The article analyses a number of four monetary forms of funerary accumulations that were found either accidentally or as a result of preventive archaeological excavations. These coins are dated during the early Roman period, were found near fortified centers (Carsium and Noviodunum) and vici type settlements (Poiana, not far from the capital of the province, Tomis) located in the territorial area of the province of Moesia Inferior. A total number of 19 bronze coins are listed, of which five sestertii, six dupondii and eight asses. The three small batches of coins and the hoard fall in the category of the funerary items voluntarily (intentionally) deposited in graves. All of them (but especially the first three) illustrate the often identified custom of leaving in the graves coins that were out of circulation for several decades or even longer. The coins had only a symbolic value, being mere decorative objects. The identified coins seem to generally confirm a carefully made selection of the reverse representations, according to a decision taken by the deceased's family for his last trip. Thus, the iconographic selection illustrates the "fashionable" mentalities and superstitions specific for the corresponding chronological periods. However, sometimes, these superstitions can also be personal, which is why the analyses have to be done differently for each situation. The presence of several coins in deposits or hoards may be linked with a particular belief regarding the necessity of paying for several passes during their trip to the underworld.
\end{abstract}

Keywords: coin offering, deposits, graves, Charon, funerary habit, Moesia Inferior.

$\mathbf{T}$ he archaeological research and, sometimes, the fortuitous findings, come to constantly enrich the funerary coin material originating from the former Roman province of Moesia Inferior. The publishing of the monetary documents completes the rest of the archaeological (where possible) and historical data provided by the other types of sources, serving for a thorough scientific research. However, this fact does not exempt a series of deficiencies regarding the limits of the numismatic
Gabriel M. Talmațchi

National History and Archaeology Museum, Constanța

gtalmatchi@yahoo.com

DOI: 10.14795/j.v7i1_SI.497

ISSN 2360 - 266X

ISSN-L 2360 - 266X 
research. For example, most often we discuss the methodology of coins publishing, starting with the fact that, for subjective and less objective reasons (depending on how the information reaches the researcher), some pieces found over the time are not brought by publication to the attention of the scientific world. Not least, another reason that might restrict the publishing of the numismatic material is determined by the conditions of finding, more exactly by the absence of the archaeological context or of the rest of the inventory in the case of closed complexes.

The use of coins in other kind of practices beside its main economic purpose is a secondary aspect of its activity. In this kind of unusual contexts, the coins have provided impressive information concerning their implication in sectors of daily life that at first glance seem to be totally unrelated to their economic aim. Obviously, due to the intervention (selection and assigning of new meanings) made by the human element, the monetary items can be connected with the religious spiritual life, more exactly the funerary practices.

The research of the ancient necropolises remains a generous source in providing information regarding the spiritual world of the human communities. The identification of the monetary pieces in clear funerary context gives us the opportunity to enter in the intimate life of the local society, within the much wider framework of what we would call the space of the dead from the inescapable daily life (as obol, according to the myth of Charon). Theoretically, for the ancient period, the coins found in graves had a precise destination, which was primarily about religious spiritual life, rite and ritual. And the placing of more pieces created the perfect context for the occurrence of some funerary deposits.

In the mid-2000s, the National History and Archaeology Museum in Constanta allotted significant funds (benefiting from support from the authorizing officer, respectively Constanta County Council) for the purchase of ancient and medieval cultural heritage items. On this occasion, the museum collections were significantly enriched with thousands of archaeological objects from private collections, of which an important number were coins. Among these fortuitous finds there were selected three funerary deposits, to which we added a monetary hoard found during the preventive archaeological researches lead by our museum. The three batches of coins are dated during the early Roman period and were found near some fortified centers like Carsium and Noviodunum and the vicus type settlements from Poiana (not far from the capital of the province, Tomis), all of them located in the territorial space of the province of Moesia Inferior. These pieces are described in the catalog below:

\section{CATALOG ${ }^{1}$ \\ Monetary deposit (no. 1)}

\section{TRAJAN}

AE; Sestertius; 7h; $22.54 \mathrm{~g} ; 32.5$ x $33 \mathrm{~mm}$.

Obverse: (IMP CAES TRAIANO O)PTIMO AVG GER DAC (P M TR P COS VI P P): Bust of Trajan, laureate, draped, right.

Reverse: (SENATVS P)OP(VLVSQVE ROMANVS S C): Felicitas, draped, standing left, holding up caduceus in right hand and cornucopiae in left.

Catalog: RIC II ${ }^{2}$, no. 671; 114 - 117 AD; mint Rome.

Findspot: Hârşova/ancient Carsium (Constanța County), before 2000s.

Inventory no. NHAM Constanţa 62.376; poor condition.

\section{ANTONINUS PIUS}

AE; Dupondius; 1h; $12.41 \mathrm{~g} ; 26$ x $24.5 \mathrm{~mm}$.

Obverse: ANTONINVS AVG (PIVS P P TR P COS III): Head of Antoninus Pius, radiate, right.

Reverse: (A)NNONA AV(G) S C: Annona, draped, standing, front, head right, holding corn-ears in right hand downwards over modius and corn-ears left and cornucopiae, tip turned outwards, in left; at right, prow of ship.

Catalog: RIC III ${ }^{3}$, no. 656; 140 - 144 AD; mint Rome.

Findspot: Hârşova/ancient Carsium (Constanţa County), before 2000s.

Inventory no. NHAM Constanța 62.375; relatively good condition.

1 The order of presentation in the catalog is correlated with the order of their entry in the specialized inventories of the National History and Archeology Museum in Constanța.

2 MATTINGLY/SYNDEHAM 1926.

3 MATTINGLY/SYNDEHAM 1930. 


\section{TRAJAN}

\section{Monetary deposit (no. 2)}

AE; Sestertius; 6h; $25.36 \mathrm{~g} ; 33 \mathrm{~mm}$.

Obverse: (IMP CAES NERVAE TRAIAN)O A(VG GER DAC P M TR P COS V P) P: Bust of Trajan, laureate, right with aegis.

Reverse: (S P Q R OPTIMO PRINCIPI S C) ARAB ADQ: Arabia, draped, standing front, head left, holding branch in right hand over camel, left, half hidden behind her and bundle of canes(?) over left arm in left.

Catalog: RIC II, no. 465/466; 103-111 AD; mint Rome. Findspot: Hârșova/ancient Carsium (Constanța County), before 2000s.

Inventory no. NHAM Constanța 64.668; poor condition.

AE; Sestertius; 5h; $22.51 \mathrm{~g} ; 32 \times 32.5 \mathrm{~mm}$.

Obverse: IMP CAES NERVAE TRAIANO AVG GE(R

DAC P M TR P COS VI P P): Bust of Trajan, laureate, draped, right.

Reverse: (SENATVS) POP(VLVSQVE ROMANVS S C): Felicitas, draped, standing left, holding winged caduceus upwards in right hand and cornucopiae in left. Catalog: RIC II, no. 634; 112 - 114 AD; mint Rome.

Findspot: Hârșova/ancient Carsium (Constanța County), before 2000s.

Inventory no. NHAM Constanța 64.676; poor condition.

\section{PHILIP THE ARAB}

AE; Sestertius; $1 \mathrm{~h} ; 15.10 \mathrm{~g} ; 27.5 \mathrm{~mm}$.

Obverse: IMP M IVL PHILIPVS AVG: Bust of Philip the Arab, laureate, draped, cuirassed, to the right

Reverse: P M S C-OL VIM / VIIII: Moesia standing, with a bull on the right and a lion on the left.

Catalog: Martin ${ }^{4}$ 2.17.1, p. 105, year VIIII, 247-248 AD; mint Viminacium.

Findspot: Hârșova/ancient Carsium (Constanța County), before 2000s.

Inventory no. NHAM Constanța 64.699; relatively good condition.

\section{Monetary deposit (no. 3) \\ FAUSTINA I (Antoninus Pius)}

AE; Sestertius; 5h; $27.24 \mathrm{~g} ; 32.3$ x $31.5 \mathrm{~mm}$.

Obverse: DIVA FAVS(TINA): Bust of Faustina I, draped, right, hair elaborately waved and coiled in bands across head and drawn up at back and piled in a round coil on top.

Reverse: (AVG)V(STA) S C: Vesta, veiled, draped, standing left, holding long torch, slightly inclined to left and palladium held on left shoulder, in left hand.

Catalog: RIC II, 1125; $141 \mathrm{AD}$; mint Rome.

Findspot: Isaccea/ancient Noviodunum (Tulcea County), before 2000s.

Inventory no. NHAM Constanța 79.021; good condition.

\footnotetext{
${ }^{4}$ MARTIN 1992.
}

MARCUS AURELIUS CAESAR (Antoninus Pius) AE; As; 5h; $9.75 \mathrm{~g} ; 26$ x $24 \mathrm{~mm}$.

Obverse: (AVRELI)VS CAES (ANTON AVG PII F): Bust of Marcus Aurelius, bare-headed, draped, right.

Reverse: TR POT X (CO)S II S C. Pietas standing, left with right hand dropping incense on candelabrum and holding box in left hand.

Catalog: RIC II, no. 1333; 155 - 156 AD; mint Rome.

Findspot: Isaccea/ancient Noviodunum (Tulcea County), before 2000s.

Inventory no. NHAM Constanţa 79.027; good condition.

\section{Coin hoard (no. 4) HADRIANUS}

AE; Dupondius; 6h; $11.39 \mathrm{~g} ; 28$ x $26 \mathrm{~mm}$.

Obverse: (HADRIAN)V(S) A(V)G COS III P P: Bust of Hadrian, laureate, right.

Reverse: AD(VENTVS) A(VG) S C: Roma, with helmet, in military dress, standing left, holding vertical spear in left hand and clasping right hands with Hadrian, togate, standing right, holding roll in left hand.

Catalog: RIC II, no. 794d; 134 - 138 AD; mint Rome.

Findspot: Poiana, Ovidiu City (Constanța County), year 2009.

Inventory no. NHAM Constanţa 81.603 ; relatively poor condition.

AELIUS CAESAR (Hadrianus)

AE; Dupondius; 6h; $11.21 \mathrm{~g} ; 27$ x $25.5 \mathrm{~mm}$.

Obverse: L AELIVS CAESAR: Bust of Lucius Aelius Caesar, bare, right.

Reverse: TR POT COS II S C: Spes, draped, advancing left, holding up lower in right hand and raising skirt with left.

Catalog: RIC II, no. 1067a; 137 AD; mint Rome.

Findspot: Poiana, Ovidiu City (Constanța County), year 2009.

Inventory no. NHAM Constanţa 81.602; good condition.

ANTONINUS PIUS (Hadrianus)

AE; As; 12h; $11.13 \mathrm{~g} ; 26.5$ x 24 mm.

Obverse: IMP T AEL CAES(AR HADR ANTONINVS):

Bust of Antoninus Pius, bare-headed, draped, right.

Reverse: (TRIB POT) COS S C: Clasped hands holding winged caduceus and two corn-ears.

Catalog: RIC II, no. 1088b; 138 AD; mint Rome.

Findspot: Poiana, Ovidiu City (Constanța County), year 2009.

Inventory no. NHAM Constanța 81.610 ; relatively good condition.

FAUSTINA I (Antoninus Pius)

AE; Dupondius; 11h; 13.59 g; 26 x $24.5 \mathrm{~mm}$.

Obverse: (DIVA FA)VSTINA: Bust of Faustina I, draped, right, hair elaborately waved and coiled in bands across head and drawn up at back and piled in a round coil on top.

Reverse: (A)ETE(R)NITAS S C: Pietas, standing left, 
raising right hand and holding box of incense.

Catalog: RIC III, no. 1161; 141 AD; mint Rome.

Findspot: Poiana, Ovidiu City (Constanța County), year 2009.

Inventory no. NHAM Constanța 81.605 ; relatively good condition.

AE; Dupondius; 6h; $12.73 \mathrm{~g} ; 26.5$ x $25.5 \mathrm{~mm}$.

Obverse: DIVA AVG FA(VSTINA): Bust of Faustina I, draped, right, hair elaborately waved and coiled in bands across head and drawn up at back and piled in a round coil on top.

Reverse: AETERNITAS S C: Pietas, standing left, raising right hand and holding box of incense.

Catalog: RIC III, no. 1161(for reverse with legend AETERNITAS), no. 1193 a (for obverse with legend DIVA AVG FAVSTINA); 141 AD; mint Rome.

Findspot: Poiana, Ovidiu City (Constanța County), year 2009.

Inventory no. NHAM Constanța 81.606; good condition.

MARCUS AURELIUS (Antoninus Pius)

AE; As; 5h; $8.49 \mathrm{~g} ; 25$ x $23.5 \mathrm{~mm}$.

Obverse: (AVRELIVS CAES ANT)ON AVG PII F: Bust of Marcus Aurelius, bare-headed, draped, right.

Reverse: (T)R POT X COS II S C: Pietas standing, left with right hand dropping incense on candelabrum and holding box in left hand.

Catalog: RIC III, no. 1333; 155 - 156 AD; mint Rome.

Findspot: Poiana, Ovidiu City (Constanța County), year 2009.

Inventory no. NHAM Constanța 81.604; good condition.

AE; As; 4h; $8.43 \mathrm{~g} ; 24.5$ × $23 \mathrm{~mm}$.

Obverse: (AVRELIVS CAES ANTON) AVG PII F: Bust of Marcus Aurelius, bare-headed, draped, right.

Reverse: TR POT X (CO)S II S C: Pietas standing, left with right hand dropping incense on candelabrum and holding box in left hand.

Catalog: RIC III, no. 1333; 155 - 156 AD; mint Rome.

Findspot: Poiana, Ovidiu City (Constanța County), year 2009.

Inventory no. NHAM Constanța 81.612 ; relatively good condition.

\section{ANTONINUS PIUS}

AE; As; 6h; $11.13 \mathrm{~g} ; 25$ x $23.5 \mathrm{~mm}$.

Obverse: (ANT)ONINVS AVG PIVS P P TR (P COS III): Head of Antoninus Pius, laureate, right.

Reverse: (IMPER)A(TOR) II S C: Libertas, standing left, holding pileus and rod.

Catalog: RIC III, no. 728; 143 - 144 AD; mint Rome.

Findspot: Poiana, Ovidiu City (Constanța County), year 2009.

Inventory no. NHAM Constanța 81.609; relatively good condition.

AE; Dupondius; 12h; 11.37 g; 26.5 x 25 mm.
Obverse: AN(TONINVS AVG) PIVS PP IMP II: Head of Antoninus Pius, laureate (not radiate), right.

Reverse: TR POT XIX COS IIII S C: Pax, draped, standing left, holding branch, extended in right hand and cornucopiae in left.

Catalog: RIC III, no. 952 (var. with 955 obverse?); 155 - 156 AD; mint Rome.

Findspot: Poiana, Ovidiu City (Constanța County), year 2009.

Inventory no. NHAM Constanța 81.607 ; relatively good condition.

AE; As; 5h; $10.96 \mathrm{~g} ; 26 \mathrm{~mm}$.

Obverse: ANTONINVS (A)VG PI VS P P TR (P) XIX:

Head of Antoninus Pius, laureate, right.

Reverse: COS IIII S C: Jupiter, seated left, holding Victory.

Catalog: RIC III, no. 954a; 155 - 156 AD; mint Rome.

Findspot: Poiana, Ovidiu City (Constanța County), year 2009.

Inventory no. NHAM Constanța 81.611; good condition.

AE; As; 6h; $12.14 \mathrm{~g} ; 25$ x $24 \mathrm{~mm}$.

Obverse: (ANTONINVS) AVG PIVS (P P IMP II): Head of Antoninus Pius, laureate, right

Reverse: TR POT XIX (COS) IIII S C: Annona, draped, seated right, holding cornucopiae in both hands: modius with grain stalks at her feet.

Catalog: RIC III, no. 956; 155 - 156 AD; mint Rome.

Findspot: Poiana, Ovidiu City (Constanța County), year 2009.

Inventory no. NHAM Constanţa 81.613; good condition.

AE; As; $11 \mathrm{~h} ; 10.29 \mathrm{~g} ; 25$ x $24.5 \mathrm{~mm}$.

Obverse: ANTONINVS AVG PIVS (P P): Head of Antoninus Pius, laureate, right.

Reverse: TR POT XXIIII COS IIII S C: Genius, naked to waist, draped, standing left, sacrificing out of patera over altar, left and holding sceptre, transverse, in left. Catalog: RIC III, no. 1052; 160 - 161 AD; mint Rome. Findspot: Poiana, Ovidiu City (Constanța County), year 2009.

Inventory no. NHAM Constanța 81.608; good condition.

The first two monetary deposits were found near the ancient Carsium, on the Danube's right bank. The site is located within the current city of Hârşova, in the area "Cetate" and it was a complex of fortifications with an uninterrupted activity for almost eighteen centuries in the same perimeter ${ }^{5}$. It was constructed at the point of contact of the Danube River with the Borcea branch,

5 TALMAȚCHI 1997, 113-124. 
near Balta Ialomiței and close to the most important crossing point from Dobruja to Muntenia. The first deposit belongs to a grave that was accidentally found and contains two bronze coins (a sestertius and a dupondius). They were minted in Rome for Trajan and Antoninus Pius between the years 114-117 $\mathrm{AD}$, respectively 140-144 AD. In the absence of any other inventory to be informed of, we propose the dating of the respective tomb soon after the middle of the $2^{\text {nd }}$ century $A D$ (perhaps at the beginning of the reign of Marcus Aurelius). The second deposit was also found by chance and contains three bronze coins of high denomination (sestertii). The first two coins were issued by the Roman emperor Trajan between the years 102-111, respectively 112-114 AD in Rome. The latest coin of the deposit is a sestertius minted in the Viminacium officina for Philip the Arab during the years 247-248 AD. Given the difficult context from the province, it is quite possible that the deposit was placed in the grave in a slightly later period than the minting moment of the coin. In this regard we note the devastating attacks of the Carpi and the Goths from the time of Philip the Arab, attacks that were closely followed by the numerous invasions of the Transdanubian populations from the years 250-253, 258-264, 267-268 $\mathrm{AD}^{6}$. Obviously, the space along the Dobrujan shore, with its fortifications chain, must have suffered significant damages during the above-mentioned events, that were specific to this period of time for a border province. Due to military events beginning with the years 248-249 AD the West-Pontic mints from Histria, Callatis and Tomis are definitively closed $^{7}$. The grave from which this batch of coins originates can be dated (in the absence of any other known inventory item) after the middle of the $3^{\text {rd }}$ century AD (up to $270 \mathrm{AD}$ ), being the latest among the analyzed deposits in this study. We believe that the bronze coin from Philip the Arab, found together with the two coins from Trajan, was added due to the

\footnotetext{
6 BUZOIANU/BĂRBULESCU 2012, 49.

7 VERTAN 2002, 33.
}

fact that it did not have a real exchange rate in the Roman territory located in the south-east of the Danube.

The third deposit it is also a fortuitous find, in the surroundings of the ancient Noviodunum / Isaccea (Tulcea County), in fact a Roman and Roman-Byzantine fortification located next to the shallow crossing from Dobruja to Moldavia. This settlement was also a former Danubian headquarter for the imperial fleet (Classis Flavia Moesica) and municipium during the early imperial time ${ }^{8}$. The two coin were minted in Rome during the reign of the emperor Antoninus Pius for his first wife, Faustina I, and for Marcus Aurelius as Caesar in the years $141 \mathrm{AD}$, respectively 155-156 AD. In the absence of any other known inventory items, we consider that the dating of the grave must be established after the middle of the $2^{\text {nd }}$ century $\mathrm{AD}$, probably towards the end of the time of Antoninus Pius or the beginning of the reign of Marcus Aurelius.

The fourth batch of pieces described in the catalog is a monetary hoard found ten years ago during some preventive archaeological researches. These were carried out during the years 2009-2011 and revealed, among others (as an example a Hellenistic settlement) ${ }^{9}$, an early Roman necropolis in Poiana (Ovidiu city, Constanța County), on the A4 motorway route ${ }^{10}$. Therefore, on $30^{\text {th }}$ of July 2009, at $\mathrm{Km}$ no. $5+400$, inside the tumulus no. 1 , was identified the grave M2, type bustum incineration grave, with a rich inventory. There were found ceramic vessels (pitchers, small cups), an oil lamp, a bronze mirror, beads, an amber ring and a monetary hoard. The last is made up of 12 bronze coins (seven asses and five dupondii) that were probably placed in a

\footnotetext{
8 BARNEA 1991, 81.

9 http://cronica.cimec.ro/detaliu.asp?k=4465.

10 About $10 \mathrm{~km}$ north of the site of the ancient Tomis, probably near the ancient road leading to Histria, a road located $2 \mathrm{~km}$ west of the shore of the present Lake Siutghiol. The preventive research aimed the unloading of the archaeological material of a sector from the bypass belt of Constanţa municipality, in the administrative territory of the city of Ovidiu and near the village of Poiana.
} 
bag made of textile material or leather, which was no longer preserved at the moment of the archaeological investigation. However, according to the information provided by the finders, on the surfaces of the coins some traces were still visible, but it was extremely hard to tell what kind of material it was ${ }^{11}$. As an observation, we should highlight the fact that the coins were placed on one side of the grave, after the incineration was completed, showing no burn marks and preserving the already mentioned organic material traces (secondary inventory). As you can see in the catalog, the hoard is opened by a dupondius from Hadrianus from the years 134-138 AD, while the latest piece was struck for Antoninus Pius in the years 160-161 AD. Specifically, the hoard contains pieces issued under Hadrianus (three pieces $-25 \%$ of the total, including from family) and Antoninus Pius (9 pieces $75 \%$ of the total, including from family). All the coins were struck in the imperial mint of Rome. As it could be concluded from a study carried out almost a decade ago, the type of graves similar with the one investigated in Poiana are very well represented among the funerary complexes known in the province of Moesia Inferior during the $1^{\text {st }}-3^{\text {rd }}$ century $\mathrm{AD}^{12}$. The $2^{\text {nd }}$ century is the densest period in terms of the use and practice of these incineration graves, especially after its middle and end $^{13}$. The necropolis from Poiana naturally belonged to a vicus $(k \omega \mu \eta)$ located nearby, which in turn was part of the economic and commercial territorial influence of Tomis, a city considered during the time of Antoninus Pius as „the brilliant metropolis and capital of the Left Pont" according to a tomb inscription made through the care of the governor $\mathrm{L}$. Minicius Natalis in the years 140/141-144 $\mathrm{AD}^{14}$. Moreover, near the locality of today,

\footnotetext{
11 Unpublished finds; the information was provided to us by our colleague Constantin Băjenaru, to whom would like to express our gratitude.

12 OȚA 2007, 75.

13 OȚA 2007, 84.

14 STOIAN 1987, 54; BĂRBULESCU/RĂDULESCU 1997, 167-170, no. 1; BUZOIANU/BĂRBULESCU 2007, 316.
}

there is a Roman road that comes from Tomis and continues to the Tomitan chora, as it can be seen through the satellite observations.

\section{INTERPRETATIONS}

What do these finds reveal to us?

Unfortunately, the references we have regarding the context of the findings of the deposits nos. 1-3 remain vague. The entrance of the coins in the Constanța's museum collections by purchase (each deposit coming from a different person) was accompanied only by the indication of their finding in fortuitous conditions. The only clues contained account of their extraction from the areas of some high banks' profiles, that presented some crack where could be seen the traces of some pits, along with human osteological remains (in one case, at Noviodunum), ceramic fragments and, sometimes, possibly tiles. In other words, the circumstances of the finding such as the context, the rite and the inventory elements will remain forever lost. The fourth, in fact a hoard, offers much more information, being discovered during the archaeological research. Including its association in the grave with ceramic vessels, jewelries, clothing accessories, various other objects for everyday use (probably betraying the Mediterranean influence of the custom). An indication regarding the sex of the incinerated person is the presence of some specific elements in the funeral inventory. Among others, the jewelries are the objects that indicate a woman's grave, but in our case, the mirror is the special item that helps in the identification process.

However, the three funerary deposits and the hoard fall into the category of the items voluntarily (intentionally) placed in the grave, having a religious character. All of them (but especially the first three) are illustrative for the custom to introduce in the graves coins that are out of circulation for several decades or for even more time. These pieces seem to be coins that either remained in the family's patrimony or were acquired from their environment in a way impossible to determine at this moment. These coins, 
without a significant financial value, were probably no longer a payment instrument, being in the end mere decorative objects.

During the last three decades, the understanding of the coin placing in the roman epoch graves particularly developed, several research directions being individualized. The results of these studies were welcomed, being extremely relevant for the comprehension of this type of social phenomenon ${ }^{15}$.

Therefore, a first observation selected by us, that is specific to the early Roman epoch, highlights the rarity of placing of several offering coins in the funeral practice (in different places of the Roman Empire) ${ }^{16}$. However, their presence can be related to the deceased's faith that he must have enough coins in order to pay the tax needed for safe crossing the river Styx towards "the world of dead" ${ }^{17}$.

The gathering of the coins from a monetary deposit or a hoard, found in a funerary context, in a bag made of organic material (like the one from Poiana) is not a unique discovery of the epoch of the early Roman Empire. Thus, we record a coin hoard preserved in an inhumation grave (no. 9), found in Brigetio (Pannonia), that was made of 23 silver and bronze coins ${ }^{18}$. Also, it is possible that the two coins that constitute de monetary deposit no. 2 to come in fact from two different graves that were mixed by the amalgamation and grinding of the soil ${ }^{19}$. But the possible presences in that place of osteological remains do no encourage this hypothesis. Therefore, we preserve the argument there were placed two coins in order to have the safety that the dead will have enough money for paying for the passing of the soul in the underworld.

15 STEVENS 1991, 215-229; GORINI 1999, 7182 ; PERASSI 1999, 43-69 ; THÜRY 1999, 17-35; BROWN 2008, 121-130; ALFÖLDY-GĂZDAC 2009, 49-78; ALFÖLDY-GĂZDAC/GĂZDAC 2009, 161174; ALFÖLDY-GĂZDAC/GĂZDAC 2013, 285-314; GĂZDAC 2014, 95-140; ALFÖLDY-GĂZDAC 2016, 1-26.

16 GORINI 1999, 76-77; GĂZDAC 2014, 97.

17 ALFÖLDY-GĂZDAC/GĂZDAC 2009, 162-163, 170.

18 ALFÖLDY-GĂZDAC/GĂZDAC 2009, 164.

19 GĂZDAC 2014, 97.
Compositionally, the three deposits and the hoard are constituted of only bronze coins (or orichalcum), being present the following denominations: sestertius (including a provincial coin), dupondius and as. The ones found accidentally have an overwhelming number of sestertii, whereas in the case of the Poiana hoard the asses (seven pieces) and then the dupondii (five pieces) predominate. However, clearly the low value denomination coins predominate (especially the as during the $2^{\text {nd }}$ century $)^{20}$. The preponderance of the bronze denomination in the necropolises of the classic period of the Roman civilization from the province of Dacia ${ }^{21}$ and from Brigetio $^{22}$ (Pannonia) can be added to the situation known for Moesia Inferior.

The Viminacium mint (from Moesia Superior) starts working in the time of Gordianus III in the years 239-240 AD and strikes coin until $255 \mathrm{AD}^{23}$. For the middle of the $3^{\text {rd }}$ century, the provincial issues were considered to be the main bronze denominations involved in the coin circulation from the area of the Middle and Lower Danube area ${ }^{24}$, being used in order to support the payment of the numerous military troops present in Pannonia and Dacia ${ }^{25}$. Also, we note from the perspective of our analysis, the finding of coins from Viminacium (P M S COL VIM) in some graves from Pannonia, a fact that would reflect the monetary policy from that province around the middle of the $3^{\text {rd }}$ century $^{26}$. In Moesia Inferior, according to the state of the research and to the findings known until the present moment, this type of pieces is extremely rare. This fact might confirm their striking mainly for the supply of nearby territories ${ }^{27}$. As findings in Dobruja we should mention two coins struck for Philip the Arab

\footnotetext{
20 GĂZDAC 2014, 101.

${ }^{21}$ ALFÖLDY-GĂZDAC 2016, 11.

22 ALFÖLDY-GĂZDAC/GĂZDAC 2009, 164.

23 MARTIN 1992, 9, 21.

24 GĂZDAC 2002, 42; GĂZDAC 2010, 105.

25 GĂZDAC/ALFÖLDY-GĂZDAC 2008, 144-146; GĂZDAC 2010, 111.

${ }^{26}$ ALFÖLDY-GĂZDAC/GĂZDAC 2009, 165.

27 HOWGEGO 1994, 10.
} 
and Philip II at Pecineaga (Constanța County) and a coin from Trebonius Gallus integrated in Dobruja passim ${ }^{28}$. Our coin issued for Philip the Arab is a sestertius, in fact the most widespread denomination known among the similar findings from Pannonia and Moesia Superior ${ }^{29}$.

Another aspect that should be analyzed is the iconography of the coins placed in the grave for the religious ritual. The choice or selection of the coins with specific representations or legends is due strictly to the personal, inter-familial choice. Their understanding is constrained by the surrounding and the expectations that flow from this act and that directly depend on each person involved. So far, in the profile research was identified a group of representations / personifications of some abstract concepts, to whom with piety and sacrifice are „requested” in front of the altars, understanding and help. For these observations were also analyzed monetary types that originated from the necropolises of Dacia and Pannonia ${ }^{30}$. These types of representations are: Aeternitas, Felicitas, Fortuna, Salus, Providentia, Spes, Libertas and Tranquillitas ${ }^{31}$. This ensures the creation of an eschatological message, in close connection with the tradition of the Charon's obol and with the vision of the afterlife.

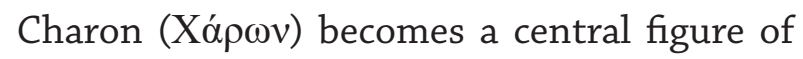
the superstitions and of the popular beliefs during the $2^{\text {nd }}$ century, a fact that could explain the growing number of the coins voluntarily placed in the graves, as well as its presence in most figurative representations ${ }^{32}$. For the time of the mentioned century (especially its middle) there can be observed a change in mentalities, a special increase in occult rites and rituals, due to the spread of the hypocrisy and credulity, at the expense of reason in the

\footnotetext{
28 VERTAN 2002, 92, 119, 447, no. 70-71, 491, no. 25.

29 GĂZDAC 2002, 42; GĂZDAC 2010, 105.

30 ALFÖLDY-GĂZDAC 2016, 12.

31 ALFÖLDY-GĂZDAC/GĂZDAC 2009, 167.

32 SOURVINOU-INWOOD 1986, 216-217; ALFÖLDYGĂZDAC 2009, 66; ALFÖLDY-GĂZDAC/GĂZDAC 2013, 303, 311; ALFÖLDY-GĂZDAC 2016, 23.
}

Empire $^{33}$. Probably, the explanation for this situation consists, as it has been observed, in the existence in the Roman society of nonhomogenous syncretic amalgam ${ }^{34}$.

Returning to the coins in the catalog, in the four batches from Carsium, Noviodunum and Poiana, we identify several personifications of goodwill: Pietas (four times), Felicitas (twice), Libertas (once), Pax (once) and Spes (once); legends such as AETERNITAS (once) and DIVA (three times); a message of the emperor's generosity through ANNONA AVG; and not least as a symbol of peace and understanding clasping hands (twice). So, theoretically, according to the list above, we can consider the possible existence of a positive selection of the monetary types according to the accompanying eschatological message. But this possibility should not be absolutized, since human factors have always been different as manifestation forms and, as a result, different particular aspects have been nuanced, from case to case.

\section{CONCLUSIONS}

The comparative analysis based on the specific data of the archaeological and the numismatic research can provide a larger picture regarding each particular funerary find. Like any historical source, the coins cannot be treated in isolation, unilaterally. On the other side, the disappearance of the archaeological context leads to the loss of numerous indications that concerns the general dating of the analyzed funerary complexes. The Roman coin (and not only) was issued to serve as an instrument in the operation of the economic and commercial life for hundreds of years on an imperial scale, on thousands and thousands of kilometers, toward each cardinal point, within the territorial limits. Its second "life" starts with its placing in the graves, the escape from the world of the living for purposes that concern the passed ones in the afterlife and their families. Just that this intentional

\footnotetext{
33 ALFÖLDY-GĂZDAC 2009, 64-65; ALFÖLDYGĂZDAC/GĂZDAC 2013, 301.

34 ALFÖLDY-GĂZDAC 2009, 73.
} 
leaving doesn't seems to have happened by chance. The pieces found in the four batches seem to confirm a generally careful choice of the iconographic representations seen on their reverse, a quite important decision taken by the deceased's family for his last journey, a decision which was made according to the "fashionable" mentalities and superstitions during those times. Sometimes these superstitions can only be personal, which is why each analysis should be specific for each situation. The presence of more coins in deposits can be linked with a particular belief regarding the necessity of paying for even more passages in the underworld ${ }^{35}$.

The religious perception, the demand for the goodwill of the divinities and the attempt to express the piousness in front of their great test was in agreement with their religious motivation and the dominant superstitions of the time. Hence the presence of the chosen coins of some deities, personifications and objects, according to some monetary types connected with the funerary ritual and also the choice of a symbol that can create a connection between the deceased and the afterlife ${ }^{36}$. For sure we can identify in the funeral ceremonies the traces of some general and particular phenomena manifested in the choice and the voluntarily placing in the graves of the coins specific to the classic period of the Roman civilization. And the analysis of the monetary types must take into account their message and any eschatological concepts.

The coins placed in the funerary contexts represented cash that was no longer used on the local monetary market, that was eliminated from the real monetary circulation (they are constituted in relics pieces). As monetary offering in the graves they had a purely symbolic value, especially those that were worn and very worn. The funerary deposits that had in their structure more pieces may, on a case by case basis, be collected in time, the chronological interval being varied also according to the realities of

\footnotetext{
35 ALFÖLDY-GÄZDAC 2016, 22.

36 PERASSI 1999, 48-52.
}

the respective epoch, to the extent of the local monetary circulation and to some particular aspects related to the deceased person or to his family (feelings, desires, insecurity). The presence of some pieces in contexts much later than the initial moment of the minting demands a special attention and an inevitable caution in their using as a chronological standard in the closed funerary inventory.

Updating and completing the information (by carefully checking of the numismatic collection of the museum of Constanța), interpreting the materials and the repertory of new finds of funerary deposits for the classic Roman period from the space of the province of Moesia Inferior are objectives that we propose to follow as part of the future topics of our future research. The present approach represents a first step in this regard.

\section{BIBLIOGRAPHY}

ALFÖLDY-GĂZDAC 2009

Alföldy-Găzdac, Á., Anatomia unui ritual.

Mărturia izvoarelor literare antice despre mitul lui Charon, EphemNap 19, 49-78.

ALFÖLDY-GĂZDAC 2016

Găzdac, Á., K., Between religious fervor and pragmatism! The coin finds within funerary context - Comparative studies between the provinces of Dacia and Pannonia, Summary of the PhD thesis, Cluj-Napoca, 1-26.

ALFÖLDY-GĂZDAC/GĂZDAC 2009

Alföldy-Găzdac, Á., Găzdac, C., Coins in Funerary Contexts. The Case of Brigetio, 161174. In: Bíró, S. (ed.), EX OFFICINA...Studia in honorem Dénes Gabler (Budapest).

ALFÖLDY-GĂZDAC/GĂZDAC 2013

Ágnes Alföldy-Găzdac, Á., Găzdac, C., „Who pays the Ferryman?". The Testimony of Ancient Sources on the Myth of Charon, Klio 95, 2, 285-314.

\section{BARNEA 1991}

Barnea, Al., Municipium Noviodunum, Peuce 10, 81-84.

\section{BĂRBULESCU/RĂDULESCU 1994}

Bărbulescu, M., Buzoianu, L., Inscripţii inedite din Tomis şi împrejurimi, Pontica 27, 157-171. 


\section{BROWN 2008}

Brown, L., Charon's Obols? A Case Study in the Role of Coins in Roman Burial Ritual Space, 121-130. In: Fenwick, C., Wiggins, M., Wythe, D. (eds.), TRAC 2007: Proceedings of the Seventeenth Annual Theoretical Roman Archaeology Conference, London 2007, (Oxford).

\section{BUZOIANU/BĂRBULESCU 2007}

Buzoianu, L., Bărbulescu, M., Tomis, 287336. In: Dimitrios Grammenos, V., Elias Petropoulos, K. (eds.), Ancient Greek Colonies in the Black Sea 2, vol. 1, BAR International Series 1675 (I), (Oxford).

BUZOIANU/BĂRBULESCU 2012

Buzoianu, L., Bărbulescu, M., Tomis. Historical and Archaeological Commentary (Constanța).

GĂZDAC 2002

Găzdac, C., Monetary Circulation in Dacia and the Provinces from the Lower Danube from Trajan to Constantine I (AD. 106-337), (ClujNapoca).

GĂZDAC 2010

Găzdac, C., Monetary circulation in Dacia and the provinces from the Middle and Lower Danube from Trajan to Constantine I (AD. 106-337), (Cluj-Napoca).

GĂZDAC 2014

Găzdac, C., Did Charon read his obol? The message of coin offering in roman graves from Pannonia, Dacia, NS., 58, 95-140.

GĂZDAC/ALFÖLDY-GĂZDAC 2008

Găzdac, C., Alföldy-Găzdac, Á., The management of a monetary crisis? The ' $P$ M S COL VIM' and PROVINCIA DACIA' coinages in the Roman monetary policy of the $3^{\text {rd }}$ century AD., Numismatische Zeitschrift 116/117, 135-171.

\section{GORINI 1999}

Gorini, G., La documentazione del Veneto per una "numismatica della morte", 71-82. In: Dubuis, O., Frey-Kupper, S., Perret, G. (eds.), Trouvailles monétaires des tombes. Actes du deuxième colloque international du Groupe Suisse pour l'étude des trouvailles monétaires (Neuchâtel, 3-4 mars 1995) (Lausanne).

HOWGEGO 1994

Howgego, Ch., Coin circulation and the integration of the Roman economy, JRA 7, 5-21.

MARTIN 1992
Martin, F., Kolonial Prägung aus Moesia Superior und Dacia, (Budapest-Bonn).

MATTINGLY/SYNDEHAM 1926

Mattingly, H., Sydenham, E., The Roman Imperial Coinage. Vol. II., Vespasian to Hadrian (London)

MATTINGLY/SYNDEHAM 1930

Mattingly, H., Sydenham, E., The Roman Imperial Coinage, vol. III, Antoninus Pius to Commodus (London).

OȚA 2007

Oţa, L., Busta in Moesia Inferior, Acta Terrae Septemcastrensis 6, 1, 75-99.

PERASSI 1999

Perassi, Cl., Monete nelle tombe di età romana imperial: casi di scelta intenzionale sulla base dei soggetti e delle scritte?, 43-69. In: Dubuis, O., Frey-Kupper, S., Perret, G. (eds.), Trouvailles monétaires des tombes. Actes du deuxième colloque international du Groupe Suisse pour l'étude des trouvailles monétaires (Neuchâtel, 3-4 mars 1995) (Lausanne).

SOURVINOU-INWOOD 1986

SOURVINOU-INWOOD, C., Charon

I. Lexicon Iconographicum Mythologiae

Classicae. III, 1, Zürich-München), 210-225.

STEVENS 1991

Stevens, S., T., Charon's Obol and Other Coins in Ancient Funerary Practice, Phoenix 45, 3, 215-229.

\section{STOIAN 1987}

I.Stoian, Inscripțiile din Scythia Minor grecești şi latine II. Tomis şi teritoriul său, (Bucureşti).

TALMAT,CHI 1997

Talmațchi, G., Considerații istorice asupra anticului Carsium (Hârșova) pe baza izvoarelor istorice, epigrafice și numismatice, Istros 8, 113-124.

\section{THÜRY 1999}

Thüry, G., E., Charon und die Funktionen der Münzen in römischen Gräbern der Kaiserzeit, 17-30. In: Dubuis, O., Frey-Kupper, S., Perret, G. (eds.), Trouvailles monétaires des tombes. Actes du deuxième colloque international du Groupe Suisse pour l'étude des trouvailles monétaires (Neuchâtel, 3-4 mars 1995) (Lausanne).

\section{VERTAN 2002}

Vertan, A., Circulaţia monetară în Dobrogea romană : secolele I - III, (Cluj-Napoca). 

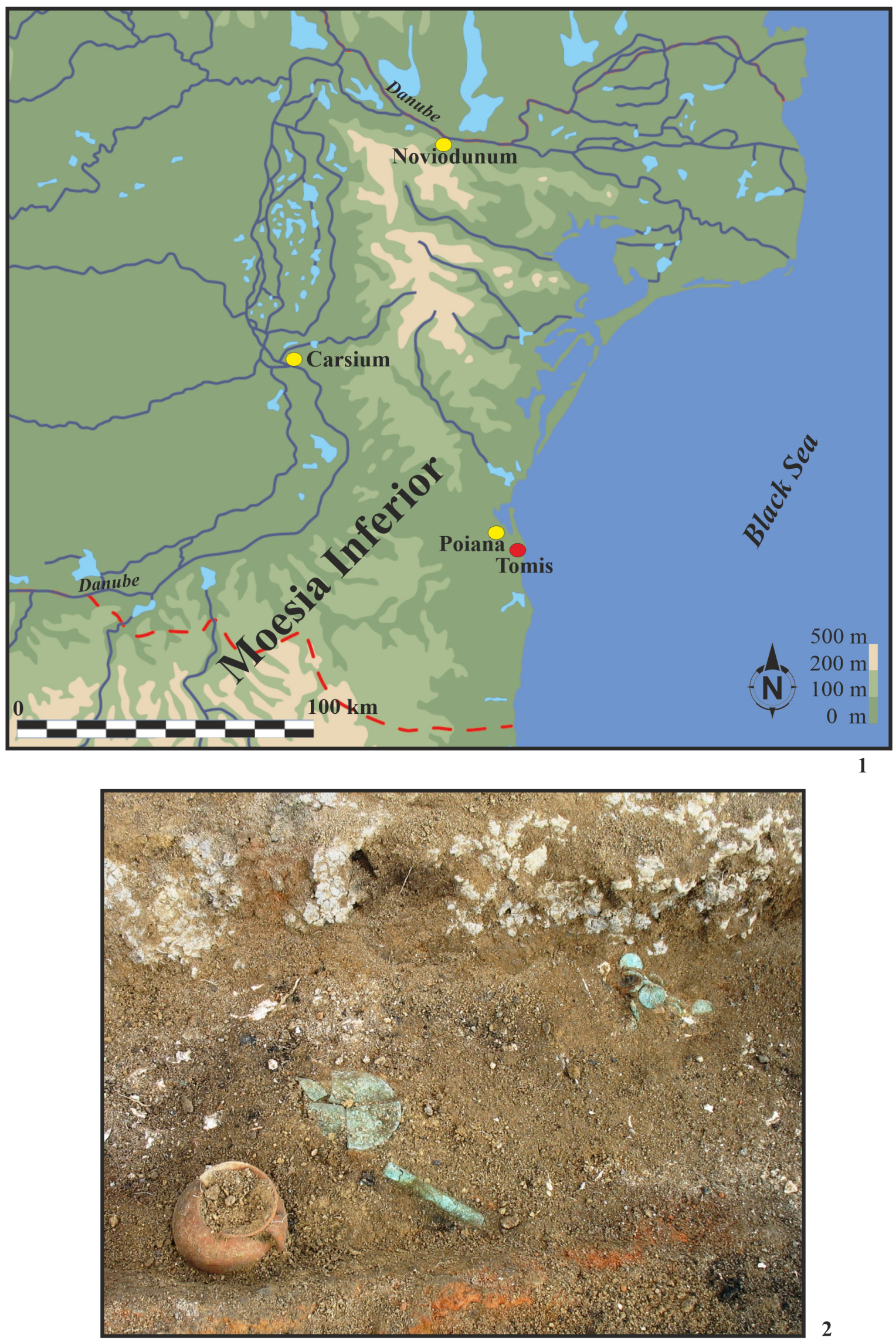

2

Plate I: 1 . The geographical localisation of the points with unpublished funerary monetary findings from Carsium, Noviodunum and Poiana/Ovidiu in the northern half of the provice of Moesia Inferior.

2. Detail of the incineration grave of the tumulus no. 1 from Poiana/Ovidiu with the coin hoard found in situ. 

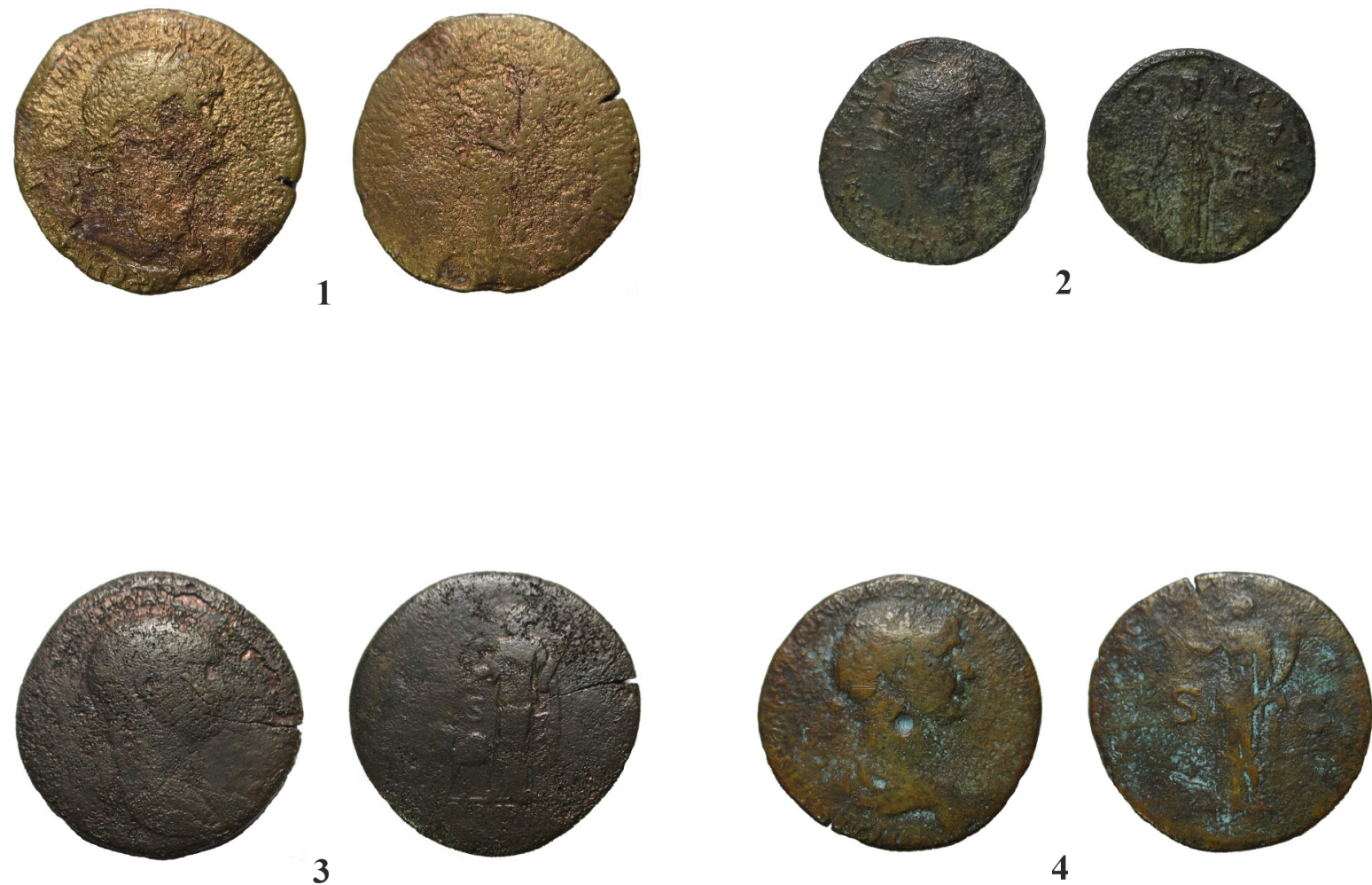

4
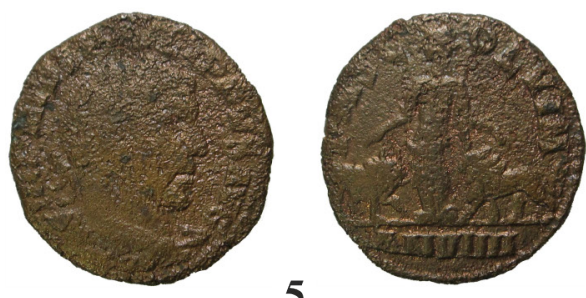

5
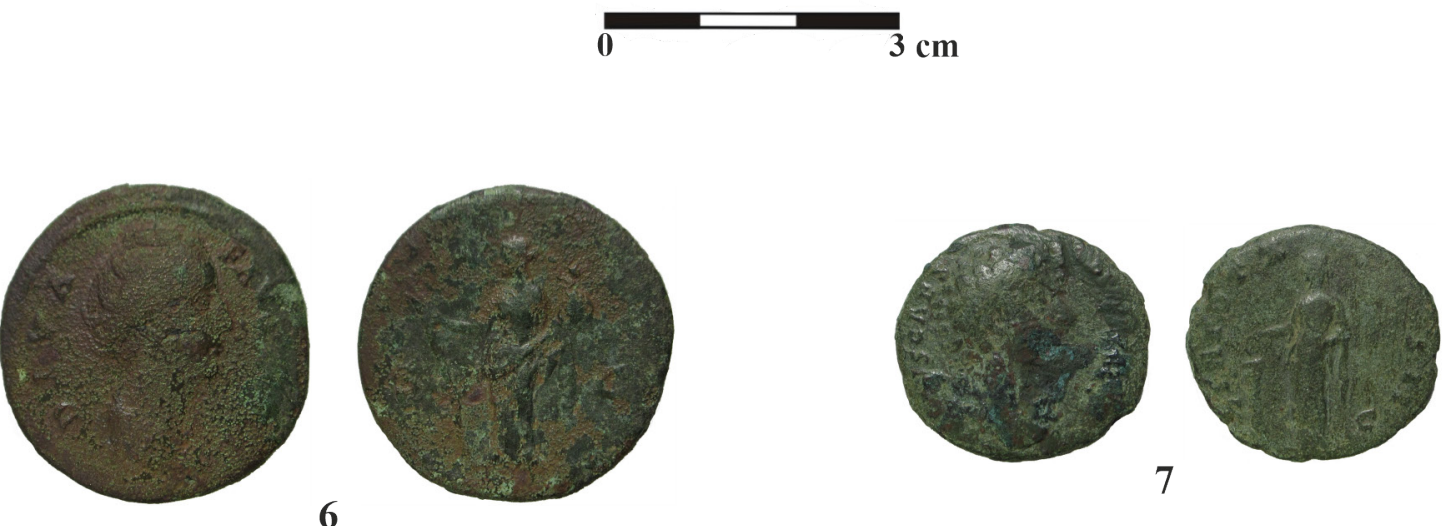

Plate II: Coins from the funerary deposits found in Carsium (1-5) and Noviodunum (6-7). 

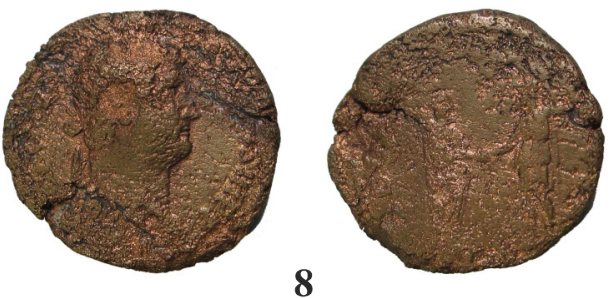

8

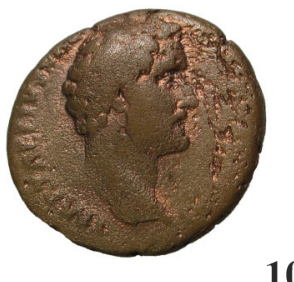

10
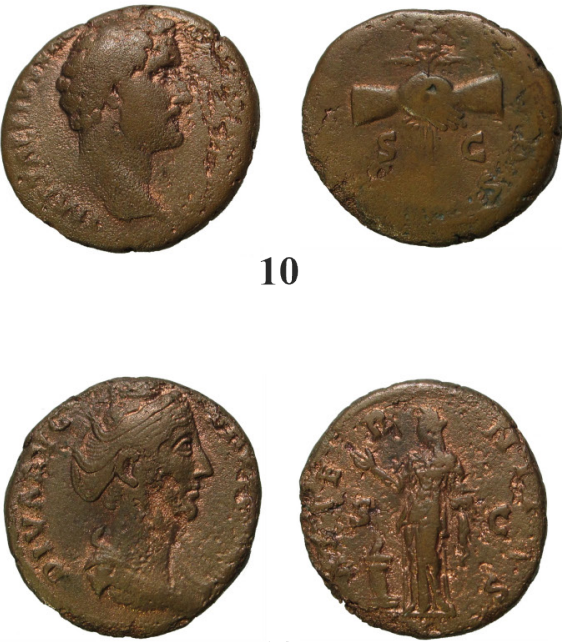

12

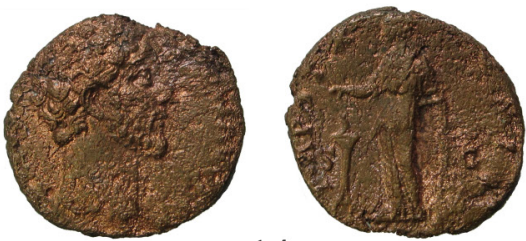

14

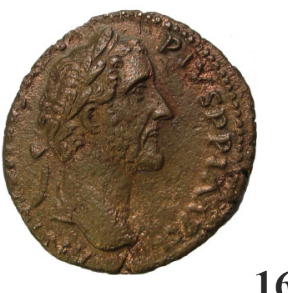

16

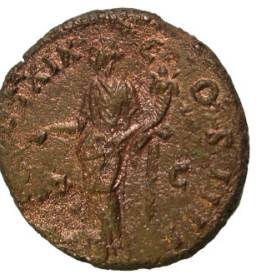

$\begin{array}{ll}0 & \mathrm{~cm}\end{array}$

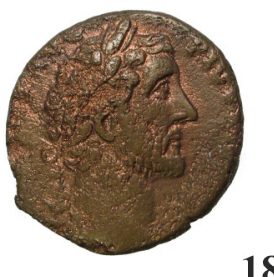

18

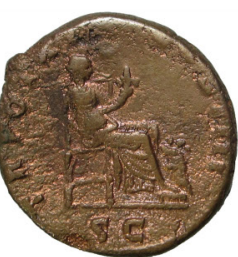

8
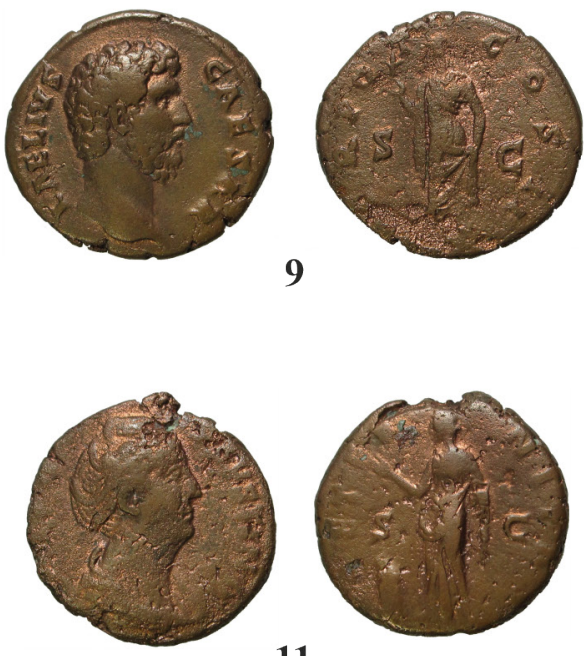

11

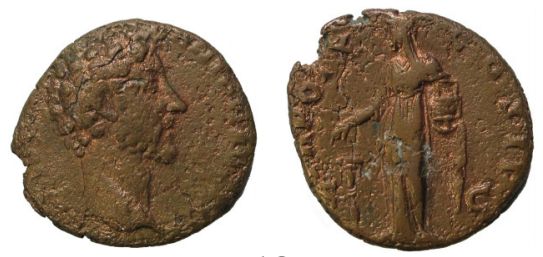

13

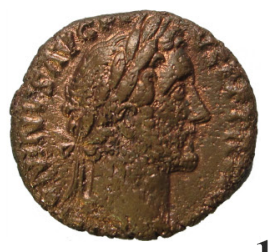

15
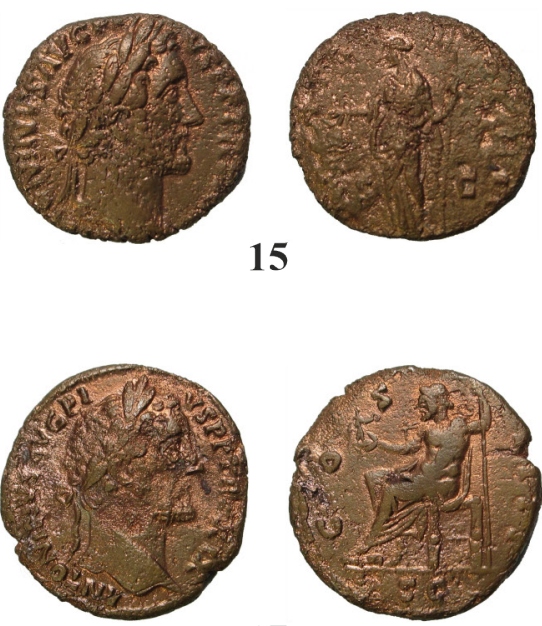

17
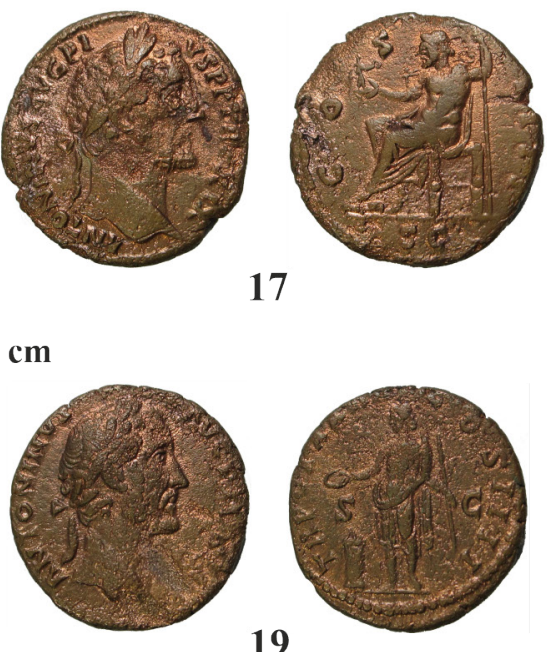

19

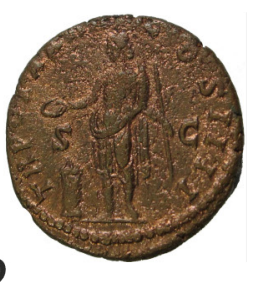

Plate III: The coins from the funerary hoard found in Poiana/Ovidiu (Constanța County) (8-19). 
